\title{
Relationships Between Individual and Family Factors and Cognitive Dimensions of Reading Comprehension Among Iranian Students
}

\author{
Maryam Sahranavard \\ Farhangian University, Tehran, Iran \\ Email address: \\ sahra1102004@yahoo.com \\ To cite this article: \\ Maryam Sahranavard. Relationships Between Individual and Family Factors and Cognitive Dimensions of Reading Comprehension Among \\ Iranian Students. Social Sciences. Vol. 6, No. 1, 2017, pp. 7-13. doi: 10.11648/j.ss.20170601.12
}

Received: October 7, 2016; Accepted: January 20, 2017; Published: February 24, 2017

\begin{abstract}
This study analyzed the relationships between individual and family cognitive factors and attitude towards reading with reading self-concept and outside reading activities and parents' literacy that are in $4^{\text {th }}$ grade Iranian students. The main of the study is based on interpretations and comprehension of PIRLS 2006. A total of 5411 students (2500 girls and 2911 boys) with average of 10.2 years old participated in PIRLS 2006 test. Reading self-concept and attitude towards reading by the student questionnaire of and outside reading activities and parents' literacy by the questionnaire of survey of learning and reading comprehension scores were tested. The results of the study showed that all the variables of cognitive comprehension of students are significant (at the level of $\mathrm{p}<0.01$ ). The reading parents' literacy was the most determination variance for students' comprehension and the reading self-concept, attitude towards reading and outside reading activities.
\end{abstract}

Keywords: Individual and Family Factors, Cognitive Dimensions, Reading Comprehension

\section{Introduction}

Lack of evaluation of learning process is difficult to understand the dimension of student learning. Danniel L. Stufflebeam stated that the evaluation process is the determination and judgment about the value of information, the objectives of educational program and the operations and its results are used to the guidance and decision making [30]. One of evaluation studies have been which have been done by some international organizations such as International Association for the Evaluation of Educational Achievement (IEA). The subject of these evaluations includes test subjects such as; Mathematics, Science, literacy, reading and some of eligibility. The test which is used for reading literacy is called PIRLS, it's the short form of Measurement, Progress in International Reading Literacy Study and it run once every 5 years in some educational systems. Iran is one of the countries that is participating in these studies. Deliberations of performance of participating countries in PIRLS, provides opportunities based on data from information and implementation status of the educational systems for other countries to study, compare and to evaluate the different aspects such as; planning, methods, textbook content, organization, factors within the school, family and sociocultural conditions [21].

Students become familiar with new ideas and information by reading skills, including ability to understanding, interpretation, inference of texts and non-tuition. They also help in better thinking and better living. The scientific and comprehensive meaning of reading literacy means endless human experience can be found [8]. In PIRLS, reading literacy is defined as; the ability of understanding and use of various forms of written language which is necessary for society and it's valuable for people. Beginners can realize the meaning of different texts. They used reading for learning, participating in school community daily life and also they use it for pleasuring [16].

This view of reading reflects a constructive and interactive process and readers to be seen as active method meanings that are familiar with effective reading strategies and methods [20]. Researchers can be aware by reading different texts about themselves and the world around. From this point of view aspects of reading are: process of understanding, goals of reading, reading behaviors and attitudes. 
Comprehension process showed that how beginners make sense of the text and interprets it. PIRLS evaluates students' comprehension by interpreting and integrating ideas, information and direct inference of the elements of text [13]. PIRLS study was designed with the focus on individual, family and school factors for providing credible information about the quality of reading in primary schools $\left(4^{\text {th }}\right.$ grades students 9 to 10 years old). PIRLS determines basic literacy reading skills of students in primary schools rather than the other learning. Therefore, there is a direct relationship between the range and the quality of academic achievement, the quality of reading, learning and understanding of courses [22]. The results of PIRLS study 2001 and 2006 showed that the performance of Iranian students with score 405 and 418 (world average $=500$ ) in comprehension are not in good condition. In another study conducted in 2006, students had a little progress towards PIRLS 2001, but from statistically point of view is not significant. Therefore, the factors influencing the results, something is inevitable [9]. There were different perspectives about literacy reading. Among all of them, the Psycholinguistic Perspective, Social constructivist perspective and Socio-Cultural perspective, paid more attention to the importance of cognitive factors for comprehension of the texts by the students. Black [2] divided the influencing factors on students' understanding and comprehension into three categories: cognitive, family and educational factors. Previous researches have been conducted using different variables as influencing factors which affected cognitive comprehension of students. In the present study, based on the former studies cognitive variables such as; individual and family reading self-concept, attitude towards reading, outside reading activities and education level of parents were used [22].

Self-concept is a set of perceptions and attitudes that someone has about him/herself or it is a set of attributes, qualities, quantities, capacity, limitations, values and relationships that people understand themselves and describe their identities [24]. James [7] has stated that "self" includes self-subjective and self-objective. Self-objective includes individual qualities, knowledge and skills. self-subjective is a person and it's an article. Many evidences supported James's theory for achieving a common definition of self-concept and the definition which is presented by Shavelson, Hubner and Stanton [25]. The following authors consider the term of selfconcept as a self-cognitive that everybody may know about $\mathrm{him} /$ herself based on the experiences and perception of the environment. Self-concept as a part of the human personality has its own nature and peculiarity. These authors tried to determine the nature of self-concept and for this purpose they pointed to seven features or seven main aspects. NamdariPejman [17] believes that self-concept has a psychological domain that is divided into multi-dimensional and hierarchical structure (general self-concept and specific selfconcept). This process is stable but when we go much lower, self-concept become more specific and ready for changing. Different shapes of self-concept such as age and sex are more separable. Self-concept includes descriptive and evaluation aspects which is more separable rather than the other structures. Zhaldman [11] believed that the self-concept has three components, cognitive component, which is connected to cognitive meaning implicit in self-concept as the qualities and roles of self-assessment and social interaction. Emotional feelings include any individual feeling which is reflected to $\mathrm{him} /$ her except any behavior that is reflected to individual behavioral. Mullis et al., [14] in their study concluded that the students who have positive self-concept in reading, read the texts for entertainment and pleasure. Accordingly, comparison PIRLS evaluation was performed in 2001 [28]. In Hong Kong, Singapore and England They reported that when a student reads something it brings valuable experience to him/her and changes him/her into a skilled reader. They also concluded that there is a positive relationship between positive self-concepts with reading comprehension and selfconcept as a fundamental concept requires the understanding of human behaviour. Rider and Susan [19] in their study of literacy in order to (something missing) reading progress tested 80 elementary students in Sydney found a positive and significant relationship between self-concept and attitude towards reading.

Aiken et al., [1] studied emotional features in three concepts; attitudes, interests and values. They claimed that attitude can be prepared for certain stimulus response. Another definition which is presented by Freedman et al., [6] emphasizes on three dimensions of cognitive, emotional and behaviour. According to this definition, attitude, including stable system of beliefs, feelings and action to prepare for what is attitude issue. This definition has three cognitive, emotional and ready for action (behaviour) elements. The definition of attitude emphasized on the word system and it has been defined to exist in the system interaction and correlation between the three components which is forming attitudes (knowledge, feeling and readiness for action). The recognition of individual feelings accepts effect from desiring about his/her practice, so changes in any of these components cause other components changing. The part of cognitive beliefs about a person or an object to the idea is formed by attitudes and beliefs. Emotional or emotional attitude related toward the emotions which makes the topic of attitude and eventually wants to practice how individual attitudes and behaviour tend to approach the subject in a certain way. Papanastasiou [18] in his study PIRLS 2001 was done among 3001 students $4^{\text {th }}$ grade in Cypriot pointed to some factors for displaying students high and low reading skills. Attitude of students to reading is stated as a significant factor. This factor has been introduced after homework, reading activities outside of school, time spent at home for homework as the fourth factor. Swalander and Taub [26] based on their study on students of eighth year in Stockholm reported the significant impact of attitude on reading self-concept and reading comprehension. Salabas [23] in his research on students of year eighth in Turkey has reached to lower correlation coefficients $(0.08)$ between attitude towards reading and comprehension skills of students. The results showed the impacts of mediator variables. 
Based on PIRLS study, students have done their outside and inside reading activity for two reasons; experience of literacy and getting and using of information. Each of these goals with specific types of texts is related together. For example, reading literacy will be formed by reading fiction texts, while reading for using information will be achieved with awareness training articles and texts [16]. Levine and Turner [12] studied that reading habits inside and outside of the school and obtained interesting results. Results showed that inside reading habits have predicted $35 \%$ of the variance comprehension and outside reading habits have predicted $36 \%$ of the variance in comprehension. Wedin and Dalarna [29] have shown in their findings that students' Tanzanian pointed to the role of outside reading activities as an important factor for the power of understanding comprehension. Folkesson and Swalander [5] in their study looked that the effects of home literacy, writing and selfconcept on comprehension as three variables. Results of the study indicated that a significant function effect of writing $(0.44)$ and a significant function effect of self-concept $(-0.30)$ on comprehension, but the impact of home literacy activities which is consisted as reading outside of school was not a significant.

Since, the Coleman et al., [4] study about the Equality of Educational Opportunity; social status was considered as an important economic variable to predict academic achievement of students. Since, in different studies this issue has been analyzed. Kiamanesh and Mahdavi-Hezaveh [10] believed that social-economic status is the value of academic background, social capital, and educational and family facilities. Thomas and Stockton [27] in their paper have concluded that there is a relationship between socialeconomic status, gender and academic achievement and girls have more power in reading literacy. They also pointed that the variable of social-economic status impacts on both sexes with a significant academic achievement of a diagnosis. Chiu and Chang [3] in a research which had done on the students with 15 years old from 43 countries using Multilevel Analysis, concluded that the reading scores of girls in all countries is higher than boys. They also found that students with a higher social-economic status have a better performance in reading literacy.

Therefore, based on importance of cognitive factors in increasing student comprehension, this study was going to review the relationship between cognitive factors with individual and family background levels from understanding and interpretations of fourth students. These factors include reading self-concept, attitude towards reading, outside reading activities, and parents' literacy. Based on these points the research hypotheses were as follow:

1. There is a significant relationship between the education level of parents and the amount of reading interpretations' students.

2. There is a significant relationship between reading selfconcept and the amount of reading interpretations' students.

3. There is a significant relationship between attitude towards reading and the amount of reading interpretations' students.

4. There is a significant relationship between reading activities outside the school and the amount of reading interpretations students.

\section{Research Methodology}

Mullis, et al., [16] stated that take-assessment reading literacy for children ( 9 years old) in PIRLS study. A population of this study was all of Iranian students who were in the $4^{\text {th }}$ grade students in 2004-2005. According to the official report of Information and Statistic Center (ISC) in 2005 there were 63,365 schools with 1,386,886 students. Therefore, based on the Institute of Statistics Canada (Threestage stratified cluster design) the researcher selected 5411 students from 235 schools (2500 girls and 2911 boys) with mean age 10.2. Data related to reading self-concept, attitude towards reading and outside reading activities was gathered by using student questionnaire and parent literacy data was gathered by questionnaire survey of parents and learning reading literacy and performance scores. In table 1, the number of questions for each scale and the reliability coefficient has been separated. Data in Table 1 indicated that the reliability coefficient was over 0.7 . It means that the internal cohesion for all variables was high.

Table 1. Number of variables, research questions and reliability coefficient.

\begin{tabular}{lll}
\hline Scale & $\begin{array}{l}\text { No of } \\
\text { Question }\end{array}$ & $\begin{array}{l}\text { Reliability } \\
\text { coefficient }\end{array}$ \\
\hline Reading self-concept & 4 & 72.0 \\
Attitude towards reading & 6 & 70.0 \\
Reading activities outside school & 7 & 73.0 \\
Parent Literacy & 4 & 82.0 \\
\hline
\end{tabular}

The number of questions for reading literacy in $4^{\text {th }}$ grade was 126 . Based on PIRLS study reading and comprehension have been measured by 10 texts ( 5 texts for the purpose of literature and 5 texts for the purpose of information). Approximately each text was accompanied by 12 questions [15]. Table 2 showed these questions to examine the type and content area. For measurement of relationships, hierarchical multivariate regression was used. This method was used for the study of effecting of one or more independent variables for predicting dependent variable.

Table 2. Questions of literacy by reading the fourth question and the type of content area.

\begin{tabular}{|c|c|c|c|c|c|c|}
\hline \multirow{2}{*}{ Context domain } & \multirow{2}{*}{$\begin{array}{l}\text { No of multiple } \\
\text { choice Question }\end{array}$} & \multicolumn{3}{|c|}{ No of construct response Question } & \multirow{2}{*}{$\begin{array}{l}\text { Total number of } \\
\text { questions }\end{array}$} & \multirow{2}{*}{$\begin{array}{l}\text { Total number of } \\
\text { scores allocated }\end{array}$} \\
\hline & & A score of 1 & A score of 2 & A score of 3 & & \\
\hline Literary & 34 & 13 & 13 & 4 & 64 & 85 \\
\hline Information & 30 & 15 & 14 & 3 & 62 & 82 \\
\hline Total & 64 & 28 & 27 & 7 & 126 & 167 \\
\hline
\end{tabular}




\section{Results}

Based on Table 3, the average scale of reading self-concept is (3.24), the attitude of students to reading is (3.5) and reading activities outside school is (3.01). Hence, they are more than expected average (2.5). Average of parents' literacy is (2.22). Hence, it is lower than the expected average.

Table 3. Mean standard deviation and range of questions which are used for measuring.

\begin{tabular}{|c|c|c|c|}
\hline Variable & Mean & Standard deviation & Spectrum Question \\
\hline Reading self-concept & 24.3 & 6.0 & 4values \\
\hline Attitude towards reading & 5.3 & 520 & 4values \\
\hline Reading activities outside school & 01.3 & 63.0 & 4values \\
\hline
\end{tabular}

Data of Table 4 showed that the questions of reading literacy performance from understanding, interpretations and analysis point of view.

Table 4. Mean standard deviation and range of reading literacy dimension changes.

\begin{tabular}{llll}
\hline Comprehension domains & Mean & $\begin{array}{l}\text { Standard } \\
\text { deviation }\end{array}$ & $\begin{array}{l}\text { Domain } \\
\text { changes }\end{array}$ \\
\hline Interpretation & 15.432 & 31.89 & 3.610 \\
Direct inference & 44.442 & 98.92 & 88.607 \\
\hline
\end{tabular}

Average of direct deduction in Table 3 was higher than interpreted and both of dimensions are less than the international standard score (500). In order to test of the assumptions, the multivariate regression analysis based on hierarchical and progressive practices were used because reading comprehension using two dimensions (understanding and direct interpretations), therefore, the multivariate regression test was run twice. The results of this test in the later interpretation were presented in Table 5, 6 and 7. Based on data in Table 5, F changes after every new variable at level $\mathrm{p}<0.01$ and is significant. In other words, all variables have significant effect on the later interpretation and understanding and totally $43 \%$ of the variance clear the interpretation.

Table 5. Summary of model variables influence cognitive interpretation procedure based on Progressive.

\begin{tabular}{|c|c|c|c|c|c|c|c|}
\hline \multirow[b]{2}{*}{ Index model } & \multirow[b]{2}{*}{$\mathbf{R}$} & \multirow[b]{2}{*}{ Square R } & \multirow{2}{*}{$\begin{array}{l}\text { Adjusted R } \\
\text { square }\end{array}$} & \multirow{2}{*}{$\begin{array}{l}\text { Average } \\
\text { standard error }\end{array}$} & \multicolumn{3}{|c|}{ Pearson and modified } \\
\hline & & & & & $\begin{array}{l}\text { R square } \\
\text { change }\end{array}$ & Change $\mathbf{F}$ & $\begin{array}{l}\text { Significant } \\
\text { changes F }\end{array}$ \\
\hline Parent Literacy & 55.0 & 30 & 3.0 & 34.73 & 30 & 96.1440 & 000.0 \\
\hline Reading self-concept & 64.0 & 410 & 410 & 27.67 & 11.0 & 61.635 & 000.0 \\
\hline Attitude towards reading & 65.0 & 430 & 43.0 & 31.66 & 02.0 & 94.98 & 000.0 \\
\hline Reading activities outside school & 66.0 & 43.0 & 43.0 & 04.66 & 01.0 & 11.28 & 000.0 \\
\hline
\end{tabular}

In Table 6 , the rate of $\mathrm{F}$ is $(641.11)$ at the level of $\mathrm{p}<0.001$. Therefore, it was significant. In other words, predictable regression coefficients showed that individual and family variables were significant for interpretation and understanding.

Table 6. Summary of logistic regression model and regression statistical interpretation of the features of cognitive variables.

\begin{tabular}{lllll}
\hline Model & Total square & Degrees of freedom & Mean square & Value F \\
\hline \multirow{3}{*}{ Regression residual total } & 92.11185307 & 4 & 98.2796326 & Significant level \\
& 47.1466508 & 3358 & 68.4361 & 11.641 \\
\hline
\end{tabular}

In Table 7 , the coefficient of cognitive variables which influence on the Pearson t showed that this variable with $99 \%$ confidence can be predicted the changes that were related to interpreted Notify variable. Calculated tolerance factors showed that there is low integration between predictable variables. It was caused of suitable choosing of variables. Correlation between the variables showed that among predictable variables parents' literacy has the highest correlation with the interpretation (0.46) and then reading self -concept variables with $(0.31)$, attitude towards reading (0.17) and outside activities with (0.09) were significant. Hence, there were significant correlations. Therefore, hypothesis of parents' literacy, reading self-concept; attitude towards reading and outside activities with reading comprehension interpretation were confirmed. The results of multiple regressions were indicated in tables 8, 9 and 10 .

Table 7. Coefficients influence of cognitive variables in regression equation.

\begin{tabular}{lllll}
\hline \multirow{2}{*}{ Index model } & \multicolumn{2}{l}{ Coefficients non-standard } & Standard coefficients & S T \\
\cline { 2 - 5 } & B & Standard error & b & 91.12 \\
\hline Constant & 2.125 & 68.9 & - & 000.0 \\
Parent Literacy & 98.30 & 2.1 & 43.0 & 37.30 \\
Reading self-concept & 9.40 & 2.2 & 28.0 & 000.0 \\
Attitude towards reading & 68.24 & 49.2 & 14.0 & 000.18 \\
Reading activities outside school & 44.10 & 97.1 & 07.0 & 9.9 \\
\hline
\end{tabular}


Table 7. Continued.

\begin{tabular}{|c|c|c|c|c|c|}
\hline \multirow{2}{*}{ Index model } & \multicolumn{3}{|c|}{ Correlations } & \multicolumn{2}{|c|}{ Statistic of the multiple linear } \\
\hline & Rank zero & Denotative & Half-denotative & Tolerance & VIF \\
\hline Constant & - & - & - & - & - \\
\hline Parent Literacy & 55.0 & 460 & 4.0 & 85.0 & 18.1 \\
\hline Reading self-concept & 47.0 & 310 & 240 & 76.0 & 32.1 \\
\hline Attitude towards reading & 34.0 & 17.0 & 13.0 & 8.0 & 25.1 \\
\hline Reading activities outside school & 27.0 & 09.0 & 07.0 & 89.0 & 13.1 \\
\hline
\end{tabular}

In Table $8, \mathrm{~F}$ changes at level $\mathrm{p}<0.01$ was significant. In other words, there was a significant for all variables, and totally contains of $43 \%$ of the variance.

Table 8. Summary of cognitive variables influencing the model based on the direct inference procedure Progressive.

\begin{tabular}{|c|c|c|c|c|c|c|c|}
\hline \multirow{2}{*}{ Index model } & \multirow{2}{*}{$\mathbf{R}$} & \multirow{2}{*}{$\begin{array}{l}\text { Square } \\
\mathbf{R}\end{array}$} & \multirow{2}{*}{$\begin{array}{l}\text { Adjusted } \\
\text { R square }\end{array}$} & \multirow{2}{*}{$\begin{array}{l}\text { Average standard } \\
\text { error }\end{array}$} & \multicolumn{3}{|c|}{ Pearson and modified } \\
\hline & & & & & R square change & Change $\mathbf{F}$ & Significant changes $F$ \\
\hline Parent Literacy & 54.0 & 290 & 290 & 30.77 & 29.0 & 58.1362 & 000.0 \\
\hline Reading self-concept & 630 & 40.0 & 400 & $71 . .23$ & 11.0 & 7.59 & 000.0 \\
\hline Attitude towards reading & 64.0 & 41.0 & 410 & 4.70 & 01.0 & 95.80 & 000.0 \\
\hline Reading activities outside school & 64.0 & 41.0 & 41.0 & 23.7 & 003.0 & 27.17 & 000.0 \\
\hline
\end{tabular}

Based on Table 9, the F rate at level $\mathrm{p}<0.001$ is (591.16). Hence, it is significant. In other words, regression coefficients predictable variables showed that cognitive individual and family variables can induct direct variance to comprehension with a significant representation.

Table 9. Summary statistical regression model and features direct to elicit regression of cognitive variables.

\begin{tabular}{|c|c|c|c|c|c|}
\hline Model & Total square & Degrees of freedom & Mean square & Value F & Significant level \\
\hline \multirow{3}{*}{ Regression residual total } & 82.116628 & 4 & 96.291569 & & \\
\hline & 66.165621 & 3358 & 12.493 & 16.59 & 0 \\
\hline & 48.282248 & 3362 & & & \\
\hline
\end{tabular}

Table 10 showed that the cognitive variable on the coefficients of Pearson t. This variable with $99 \%$ confidence can be interpreted Notify variable to predict. The tolerance for variables can be predicted low levels of time variables. The correlation between the variables represented the relationship between parental education which has a direct corollary to direct inference $(0.45)$ and then reading Selfconcept variables $(0.03)$, attitude towards reading $(0.16)$ and outside activities (0.07) were Significant. Therefore, hypothesis of parental literacy, Self-concept reading, attitude towards reading and outside activities was confirmed.

Table 10. Coefficients effect of cognitive variables in regression equation.

\begin{tabular}{lllll}
\hline \multirow{2}{*}{ Index model } & \multicolumn{2}{l}{ Coefficients non-standard } & \multicolumn{2}{l}{ Standard coefficients } \\
\cline { 2 - 4 } Significant level \\
\cline { 2 - 4 } Constant & B & Standard error & b & \\
Parent Literacy & 91.135 & 29.10 & - & 2.13 \\
Reading self-concept & 7.32 & 8.1 & 42.0 & 56.29 \\
Attitude towards reading & 81.42 & 34.2 & 28.0 & 000.0 \\
Reading activities outside school & 73.23 & 65.2 & 13.0 & 000.0 \\
\hline
\end{tabular}

Table 10. Continued.

\begin{tabular}{llllll}
\hline \multirow{2}{*}{ Index model } & Correlations & & & \multicolumn{2}{c}{ Statistic of the multiple linear } \\
\cline { 2 - 6 } & Rank zero & Denotative & Half-denotative & Tolerance & VIF \\
\hline Constant & - & - & - & - & - \\
Parent Literacy & 540 & 45.0 & 390 & 85.0 & 18.1 \\
Reading self-concept & 46.0 & 30.0 & 24.0 & 760 & 32.1 \\
Attitude towards reading & 33.0 & 16.0 & 12.0 & 80 & 25.1 \\
Reading activities outside school & 26.0 & 07.0 & 06.0 & 89.0 & 13.1 \\
\hline
\end{tabular}

\section{Discussion}

This study analyzed PIRLS 2006 in reading comprehension of students with two dimensions, interpretations and direct relationship; and then the relationship between these two individual cognitive and family factors were analyzed. The results of data analysis indicated that there was a significant relationship between parents' literacy and direct interpretations of reading students. This variable had the main effect of students understanding (interpretation $=0.46$ and inference $=0.45$ ). 
The result of this study was in line with the results other of studies such as; Thomas and Stockton [27] and Chiu and Chang [3]. They also achieved a significant relationship between parental literacy and academic achievement in reading.

\section{Conclusion}

The relationship between student reading self-concept and interpretations of reading comprehension was one of the hypotheses of the research. The results of the study showed that the variables were a positive and significant relationship with fancy and it was about 0.30 of variance to comprehension and representation. The findings of this study were in line with the results other of studies such as; Mullis et al., [14], Tse, et al., [28] and Rider and Susan [19]. They showed that the imagination of students who have positive reading material was for entertainment and pleasure. While a student reads something for him/herself, it made him/her to a skilled reader with a valuable experience [20]. The result of this study was in line with the results other of studies such as; Folkesson and Swalander [5] study except it was opposite of it.

The other hypothesis of the research was the relationship between students' reading attitude in interpretations of reading comprehension. The data of the study was determined that the attitude toward reading was significant in understanding and it showed that about 0.17 of understanding of variance. Therefore, the findings of this study were in line with the results other of studies such as; Papanastasiou [18] and Swalander and Taube [26]. However, attitude was not the same. Hence, Salabas [23] achieved lower correlation coefficients (0.08). Namdari-Pejman [17] achieved the correlation coefficients (0.28). Since his study was based on structural equation modeling in using variables to intermediate.

The last hypothesis of the study was outside reading activities and the level of dimensions of comprehension. Based on the results, the relationship between outside reading activities and the level of dimensions of comprehension was significant. Outside activities was the minimum variance representation of understanding significant (00.07). The findings of this study were in line with the results other of studies such as; Levine and Turner [12], Wedin and Dalarna [29], Folkesson and Swalander [5].

\section{References}

[1] Aiken, L. R., Gambell, T. J., McNinch, G. H., Arnold, E., Richmond, M. G., Halpin, G., et al. (1981). Volume 6. Summer 1981 Number 2. Educational research quarterly: ERQ. 6 (2).

[2] Black, A. L. (2006). Attitudes to reading: An investigation across the primary years. Australian Catholic University.

[3] Chiu, M. M., \& Chang, C. M. (2006). Gender, Context and Reading: A Comparison of Students in 43 Countries. Chinese university of Hong Kong.

[4] Coleman, J. S., Campbell, E. Q., Hobson, C. J., McPartland, J., Mood, A. M., Weinfeld, F. D., et. al. (1966). York. 1966. Equality of educational opportunity.

[5] Folkesson, A., \& Swalander, L. (2007). Self-regulated learning through writing on computers: Consequences for reading comprehension. Available at: www.elsevier.com/locate/comphumbeh.

[6] Freedman, L. P., Luisi, B. F., Korszun, Z. R., Basavappa, R., Sigler, P. B., \& Yamamoto, K. R. (1988). The function and structure of the metal coordination sites within the glucocorticoid receptor DNA binding domain.

[7] James, W. (1983). The principles of psychology. Harvard University Press. (Original work published 1890), Cambridge.

[8] Karimi, A. (2005). Review results of reading literacy study international development PRLS 2001. Journal of Education, $21(1), 89-39$.

[9] Karimi, A. (2008). International study results in 2006 compared with PRLS PRLS 2001.. Research Studies of Education, Special PRLS 2006 results, in November.

[10] Kiamanesh, A. R., \& Mahdavi-Hezaveh, M. (2008). Influential Factors causing the gender differences in mathematics' achievement scores among Iranian Eight graders based on TIMSS 2003 data. Paper presented at the Proceedings of the IRC-2008 TIMSS, Taiwan, Available: www.iea.nl/.../TIMSS_Mathematics/Kiamanesh_Mahdavi_He zaveh.pdf.

[11] Zhaldman, I. (2006). Self-Concept and School Achievement of Pupils with Cleft Lip, Cleft Palate or both: A Longitudinal Study. Helsinki: Yilopistopaino.

[12] Levine, C., \& Turner, M. W. (2001). Reading for pleasure: Gender and popular genres. Journal of Popular Culture, 35 (1), $1-4$.

[13] Martin, M. O., Mullis, I. V. S., \& Kennedy, A. (2007). PIRLS 2006 Technical Report. Boston College: TIMSS \& PIRLS international study center.

[14] Mullis, I. S., Martin, M. O., Gonzalez, E. J., \& Kennedy, A. M. (2003). PIRLS 2001 International Report: IEA's Study of Reading Literacy Achievement in Primary School in 35 countries: Chestnut Hill, MA: Boston College.

[15] Mullis, I. V., Martin, M. O., Kennedy, A. M., \& Foy, P. (2007). PIRLS 2006 International Report: Boston College: TIMSS \& PIRLS international study center.

[16] Mullis, I. V. S., Kennedy, A., Martin, M. O., \& Sainsbury, M. (2006). Assessment Framework and Specifications ((2nd Ed) ed.): Boston College: International association for the evaluation achievement.

[17] Namdari Pejman, M. (2008). The relationship self-concept, preschool activities, attitude towards reading in parents and students with reading performance of students in reading literacy by the fourth primary (based on studies PRLS 2006). Teacher Training University, Tehran.

[18] Papanastasiou, C. (2006). Factors that distinguish the most from the least effective schools in reading: A residual approach. Paper presented at the Second IEA International Research Conference. 
[19] Rider, N., \& Susan, c. (2006). Reading Achievement and Reading Self-Concept in Year 3 Children. Australia: NSW, COL05347.

[20] Ruddell, R. B., \& Unrau, N. J. (Ed.). (2004). Theoretical Models and Processes of Reading (5th ed.): Newark, DE: International Reading Association.

[21] Sahranavard, M. (2015). Gender Differences in Science Performance among Iranian Students in TIMSS 2007. International Journal on Recent Trends in Life Science and Mathematics (IJLSM). 2 (3): 2349-7955.

[22] Sahranavard, M. Namdari-Pezhman, M. (2016). The Relationships between Cognitive Factors and Reading Comprehension among Iranian $4^{\text {th }}$ grades students in PIRLS 2006, 15 (2): 74-80.

[23] Salabas, M. E. (2008). Relationship between 8th grade secondary school students' reading attitudes and reading comprehension skills. Journal of the Faculty of Education, 9 (16), 141-155.

[24] Sanchez, F., \& Roda, M. (2003). Relationships between selfconcept and academic achievement in primary students. Electronic Journal of Research in Educational Psychology and Psycho Pedagogy, 1 (1), 95-120.
[25] Shavelson, R. J., Hubner, J. J., \& Stanton, G. C. (1976). Selfconcept: Validation of construct interpretations. Review of Educational Research, 46 (3), 407.

[26] Swalander, L., \& Taube, K. (2006). Influences of family based prerequisites, reading attitude and self-regulation on reading ability. Available on Site: www.sciencedirect.com.

[27] Thomas, J., \& Stockton, C. (2003). Socioeconomic status, race, gender, \& retention: Impact on student achievement. Available at site: www.usca.edu/essays/vol72003/stockton.pdf.

[28] Tse, K. S., Raymond, Y. J. L., Joseph, W. I. L., Yiu, M. c., \& Elizabeth, K. Y. L. (2005). Attitudes and attainment: A comparison of Hong Kong, Singaporean and English students' reading. University of Hong Kong, Research in Education, 76, $74-88$

[29] Wedin, A., \& Dalarna, H. (2005). The Relationship between Literacy and Power: The Case of Literacy Practices in and out of School in Karagwe. Paper presented at the Proceedings of the 14th European Conference on Reading Zagreb Croatia, Tanzania.

[30] Wolf, R. I. (1984). Educational Evaluation: based on ability to measure and review program. 